were observed in early July 1976 along creekside shrub habitats.

RED ADMIRAL (Vanessa atalanta). Observed in cottonwood stands.

MOURNING CLOAK (Nymphalis antiopa). Observed in tall shrub and poplar stands.

PEARL CRESCENT (Phyciodes tharos pulchella). June 7 , June 10, 1974; June 29, 1975. Found in low shrub areas.

CARLOTA CHECKERSPOT (Chlosyne gorgone carlota). June 10, 1974. Found in low shrub and grassy areas.

ACASTA CHECKERSPOT (Chlosyne acastus acastus). June 30, July 5, 1974; June 30,1975 . Found in coulee bottoms containing sagebrush, greasewood and grasses. This species is previously known in Alberta only from badland areas along the Red Deer and Oldman River systems.

EDWARD'S FRITILLARY (Speyeria edwardsii). July 21, 1967. Collected by A. G. Edmund.

CALLIPPE FRITILLARY (Speyeria callippe calgariana). July 1 , July 3 , July 5 , 1974; July 24, 1975 . Found in mixed prairie areas.

APHRODITE (Speyeria aphrodite mayae). July 24, 1975. Found in long grass and shrub areas.

RINGLET (Coenonympha inornata benjamini). June 7,1974 ; June 29, 1975. Found in grassland areas.

COMMON WOOD NYMPH (Cercyonis pegala ino). July 6, August 3, 1974; July 24, 1975. Found in most grass and shrub areas.
SMALL WOOD NYMPH (Cercyonis oe charon). June 30 , July 8,1974 ; July 24,19 Found in areas of sagebrush a greasewood.

RIDING'S SATYR (Neominois riding ridingsii). July 3, 1973. Collected by Hilchie.

VARUNA ARCTIC (Oeneis uhleri varun June 7 , June 10, June 11, 1974. Found mixed grassland areas.

'BIRD, C. D. and N. KONDLA. 1974. Sor skippers and butterflies from Dinosa Provincial Park, Alberta. Blue Jay $87-88$.

2BROWN, F. M. 1960. A badlands sL species of Limenitis weidemey Edwards (Lepidoptera, Nymphalida American Museum Novitates, Numb 2018, 6 pp.

${ }^{3}$ GREGORY, W. W. 1975. Check-list of $t$ butterflies and skippers of Cana Lyman Entomological Museum a Research Laboratory Memoir No. 1975.

${ }^{4}$ HOOPER, R. 1974. Butterflies of Sask chewan. Saskatchewan Department Renewable Resources.

${ }^{5}$ SOPER, J. D. 1949. Notes on the fau of the former Nemiskam National $P$ and vicinity, Alberta. Canadian Fi Naturalist 63: 167-182.

${ }^{6}$ THOMAS, M. K. 1953. Climatologi atlas of Canada. Canada Department Transport. Ottawa 255 pp.

\title{
A SNAKE'S WINTER
}

\section{ALEXANDER W. L. HAWLEY*}

Any animal that lives year-round in the Prairie Provinces must tolerate long and cold winters. Different animals cope with these severe conditions in different ways. Many homeotherms (warm-blooded animals) are capable of staying active throughout the winter if food remains available. Maintenance of a high metabolic rate and good insulation

*Condensed from Manitoba Nature, Vol. 14, No. 3, Autumn, 1973. (i.e., hair, feathers, and subdermal $f$ permit maintaining a bo temperature high enough to allow tivity. Some homeotherms becor torpid during the winter, occasiona becoming active to feed on stor food. Others, particularly tho whose food source essentially $c$ appears for the winter, cannot me the high energy demands of stayi active under such cold conditions a are forced to hibernate.

Since their body temperature 
pressed during hibernation, meotherms select their rwintering sites to avoid freezing peratures. However, if by chance environmental temperature drops vithin one or two degrees of freezmost homeotherms are aroused increase their metabolism, thus easing body temperature. This ws them to become active, and sibly seek more suitable shelter.

oikilotherms (cold-blooded mals) do not display this wide ge of capabilities. They produce tively less metabolic heat than neotherms. With no effective surinsulation such as hair or hers, and little subdermal fat, ir body temperature depends on temperature of their immediate oundings and what heat they can orb from the sun's rays. Unless $e$ is an external source of heat as sunlight, temperatures below at which ice forms in their tissues quickly kill most poikilotherms.

$s$ all poikilotherms in this area t hibernate, and they must do it in heltered place. The Red-sided ter Snake (Thamnophis sirtalis etalis) is particularly interesting. only is it the most common repin Manitoba, but it lives farther th than any other reptile on this tinent. Thus it is likely this ilotherm has developed a good hanism for surviving the winter.

ie Red-sided Garter Snake ess low winter temperatures by gounderground. Not being a very $d$ burrower, this snake relies on iral accesses to the soil to get w the frost line. For this reason it rgely confined to the more rocky as of the province like the rlake. Here water erosion has ted many cracks and fissures in limestone. In some places subanean erosion has created larger erns and limestone sinks (caverns series of fissures which have psed creating a rocky pit). These serve as natural hibernacula for snakes.

is species dens communally and ie fall tens of thousands of garter es congregate around the hiber- nacula. The snakes start collecting around the den sites in early September. When temperatures drop at night they seek shelter in the hibernaculum, re-emerging the next day. As the weather gets colder, fewer snakes remain active, and these spend less time above the surface. The last animals finally disappear underground around late October ... Low environmental temperatures will depress the snakes' body temperatures. Decrease body temperature will decrease all body activity. Thus the snakes are unable to move very far or very fast in the cold. Because of this, they could be trapped above ground for the winter by low late-autumn temperatures if they were not already at the den site.

The original selection of a hibernaculum is probably a function of accessibility to frost-free areas, and it appears that almost any access route will do. Several hundred snakes now use the foundation of the creamery at Inwood, Manitoba, as a hibernaculum. The creamery may have been built over an already-active den without deterring the snakes... Or, it could have developed as a denning site after its construction. Several of the local residents have snakes hibernating in their basements and barns. Although some people have an aversion to this harmless little snake and object to the intrusion, it was probably the people who intruded on the snakes.

Young snakes do not spend their first winter at a communal den. They are born in August at or near the areas of summer habitation. Although it is almost certainly someplace underground, no one knows exactly where they spend the first winter. They might overwinter individually in smaller fissures and openings in the rock. Young garter snakes have, on occasion, been found in anthills, and these have been suggested as possible overwintering sites. The second is spent at a communal den. What causes a snake to make this change in denning habits is also unknown. We do know that once a hibernaculum is selected, the snakes tend to return to 


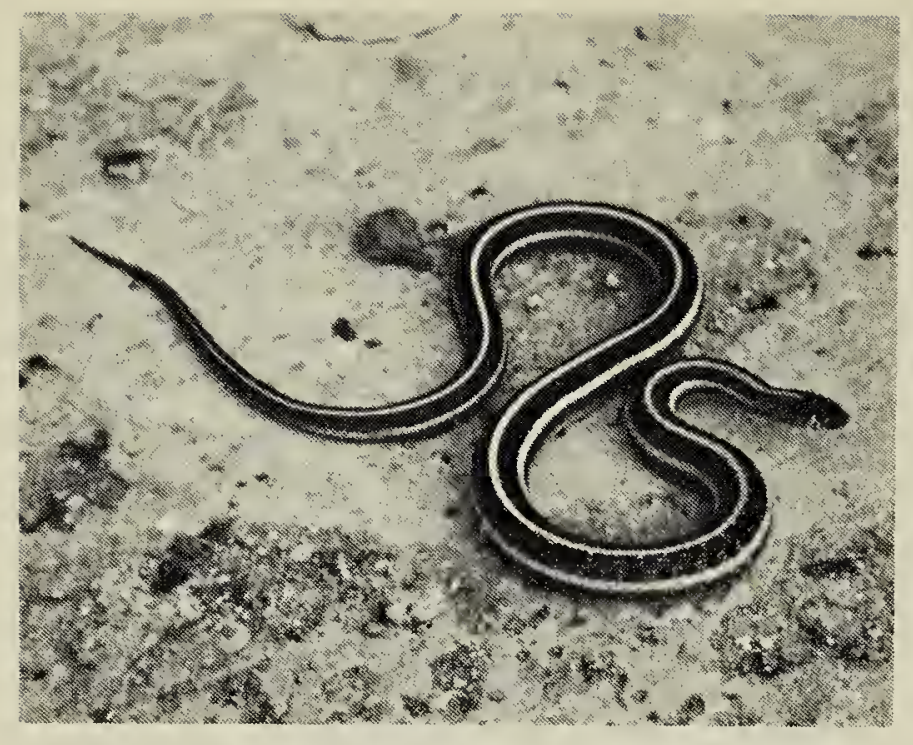

Garter Snake

J. B. Gollop

the same den year after year. That is, the snakes display a homing instinct like many other migratory animals.

What happens to the snakes during their six months underground? We really don't know. It is only with a decreased metabolic rate that animals can survive such long periods of fasting. Mammals must invoke special mechanisms to decrease their body temperatures. Of course, to a snake this is the normal conditon. The lowered temperature decreases the rate of the body's reactions. We don't know exactly what the temperatures are in dens during the winter. The lowest temperature recorded in one den was $1^{\circ} \mathrm{C}\left(34^{\circ} \mathrm{F}\right)$, but in places it may get colder. The Red-sided Garter Snake has a certain resistance to cold. It can tolerate $-10^{\circ} \mathrm{C}\left(14^{\circ} \mathrm{F}\right)$ for onehalf hour or more. It appears that this resistance increases with increased cold exposure, so that in the winter the snakes are most capable of tolerating low tempertures. But the snakes freeze after prolonged exposure to such cold.

Poikilothermic vertebrates cannot tolerate actual freezing. Once their tissues have frozen, they have little capacity for revival when thawed. However these animals may be able to indefinitely resist freezing at temperatures only a few degrees below $0^{\circ} \mathrm{C}\left(32^{\circ} \mathrm{F}\right)$. There are several possible ways to do this. One is to increase the concentration of solutes in the body fluids which depresses the actual freezing point of the fluids.
Another involves the phenomenon supercooling. The "freezing point' the highest temperature at which can exist in a solution. Supercooling the condition in which the tiss temperature is below its freezi point without the formation of $i$ The mechanism of supercooling tissues and cells involves nothi more than the physico-chemi nature of water and the spontaned formation of ice crystals. Even pt water can be supercooled to -20 $\left(-4^{\circ} \mathrm{F}\right)$ and lower. There is reason believe that the capacity to superc might vary from species to species might also vary with the state hydration of an animal, or 1 temperatures to which it has be recently exposed.

The Plains Garter Snake (Th nophis radix), another species fou in Manitoba, has been found hibernate successfully at $-2^{\circ} \mathrm{C}(28$ This suggests a long-term sup cooling capacity. The Red-sic Garter Snake may also have capacity. All these means of surv involve a tolerance of I temperatures. Unlike mammals, th is little a garter snake can do to crease its body temperature eithe increasing its metabolic rate or shi ing.

Despite the various mechani this snake has evolved to survive winter, there still apears to be a t degree of overwintering morta Perhaps many of the snakes don't deep enough underground to as freezing. Or perhaps many die $f$ lack of oxygen. We may never $k n$ Like so much of our knowledge of adaptations these reptiles have $m$ to survive our harsh climate, we still very much out in the cold. 